\title{
Energy efficiency and moisture diffusivity of apple slices during convective drying
}

\author{
Mohsen BEIGI ${ }^{1 *}$
}

\begin{abstract}
The present study aimed at investigating the influences of drying air temperature and flow rate on energy parameters and dehydration behaviour of apple slices. For this purpose, apple slices were dried in a convective dryer at air temperatures of 50,60 and $70{ }^{\circ} \mathrm{C}$, and air velocities of $1,1.5$ and $2 \mathrm{~m} \mathrm{~s}^{-1}$. Dehydration rate increased as the air temperature and flow rate increased from 50 to $70{ }^{\circ} \mathrm{C}$ and 1 to $2 \mathrm{~m} \mathrm{~s}^{-1}$, respectively. The effective moisture diffusivity was determined to be in the range of $6.75 \times 10^{-10}-1.28 \times 10^{-9} \mathrm{~m}^{2} \mathrm{~s}^{-1}$. Results of data analysis showed that the maximum energy consumption $(23.94 \mathrm{~kW} \mathrm{~h})$ belonged to $50^{\circ} \mathrm{C}$ and $2 \mathrm{~m} \mathrm{~s}^{-1}$ and the minimum $(13.89 \mathrm{~kW} \mathrm{~h})$ belonged to $70{ }^{\circ} \mathrm{C}$ and $1 \mathrm{~m} \mathrm{~s}^{-1}$ treatment. Energy efficiency values were in the range of $2.87-9.11 \%$. Moreover, the results indicated that any increment in the air temperature increases thermal and drying efficiencies while any increment in the air flow rate decreases both of them.
\end{abstract}

Keywords: apple; moisture diffusion; thermodynamic parameters; energy efficiency.

Practical Application: Traditional drying methods pose some problems such as long drying time and dust and microbial contamination of the dried materials. Artificial drying methods should be employed to overcome these problems. In spite of some advantages for industrial dryers, energy requirement in drying technology is one of the key problems to overcome. The drying process generally consumes large amounts of energy; therefore, it is crucial to make sure of high energy efficiency and low environmental impact in this process.

\section{Introduction}

Drying is one of the most common techniques used to reduce microbiological activity and to improve the stability of moist materials by decreasing their moisture content to a certain value (Torki-Harchegani et al., 2015). Traditional drying, e.g., open sun and shade methods, have been employed for the dehydration of agricultural products since a long time ago. Notwithstanding their low investment costs and simplicity, traditional drying methods pose some problems such as dust and microbial contamination of the dried materials as well as long drying time (Soysal, 2004). To overcome these problems, it is necessary to employ artificial dryers for the dehydration of agricultural and food products (Demiray \& Tulek, 2012).

Although more than 400 types of different dryers are reported in the literature to dry plants and foodstuff, convective dryers are the most widely used devices to dehydrate agricultural products (Aghbashlo et al., 2013). In this process, several heat and mass transfer mechanisms occur but, diffusion within the product is considered as the dominant factor controlling moisture transfer from inside of the product to its surface. Then, the water is transferred from the product and air interface to the air stream by convection (Beigi, 2015).

Drying process utilizes high energy compared to other production processes due to relatively low energy efficiency of dryers and high latent heat of water evaporation (Syahrul et al., 2002). Drying consumes $10-15 \%$ of the total national industrial energy demand in Canada, France and the USA, as well as 20-25\% in Germany and Denmark (Motevali et al., 2014). Therefore, it is the most important challenge for the drying industry to perform energy analysis to achieve optimum process conditions and reduction of energy utilization. Energy analysis is practical in quantitative evaluation of energy requirements and energy losses in drying systems. Moreover, information obtained from energy analysis is useful to design new dryers, to optimize the drying parameters, and even to design energy recovery systems.

The main objectives of this study were to dry apple slices in a convective hot air dryer and to investigate the effect of air temperature and flow rate on drying kinetic and effective moisture diffusivity of the samples as well as total energy consumption, energy efficiency, drying efficiency and thermal efficiency of the process.

\section{Materials and methods}

\subsection{Drying experiments}

The fresh apples used in this study were purchased from a local market in Isfahan (central Iran) and stored in a refrigerator at $4-8{ }^{\circ} \mathrm{C}$ until the experiments started. The average initial moisture content of the fresh samples was determined using standard oven method at $103{ }^{\circ} \mathrm{C}$ until constant weight was achieved (Schössler et al., 2012), and obtained approximately $0.83 \mathrm{~g}_{\text {water }} / \mathrm{g}_{\text {wet matter }}$ Prior to each experiment, the apples were placed at room temperature for about $2 \mathrm{~h}$ so that they would reach thermal equilibrium with the environment. For each drying experiment, the apples were washed with water, hand 
peeled and cut into $4 \mathrm{~mm}$ thickness, and approximately $500 \mathrm{~g}$ of the samples were spread as a monolayer on the tray.

To conduct the drying experiments, a laboratory-scale convective hot air dryer was designed and fabricated (Figure 1). The drying air was supplied by a centrifugal fan, blown into an electrical heater to heat up to the desired temperature and then passed to the drying chamber. The drying air velocity was measured by a portable hot wire anemometer (Lutron, AM-4201 model, Taiwan) and was controlled by using a frequency inverter (TECO, $7300 \mathrm{CV}$ model, Taiwan). Temperature of the drying air was measured by a thermometer (PT100, $0.1{ }^{\circ} \mathrm{C}$ resolution) in the drying chamber inlet and controlled by using a microcontroller.

The drying experiments were performed at air flow rates of $1,1.5$ and $2 \mathrm{~m} \mathrm{~s}^{-1}$; and temperatures of 50,60 , and $70^{\circ} \mathrm{C}$ in an air relative humidity remained at constant level of $30 \%$ using an ultrasonic humidifier equipped with a microcontroller.

For each experiment, the dryer was run to reach a steady state conditions for the set point (at least $40 \mathrm{~min}$ ), and then the samples tray was placed on the drying chamber. The samples mass was monitored with a digital balance accurate to $0.001 \mathrm{~g}$ (ViBRA, model EG 620-3NM, Japan) at regular time intervals of $5 \mathrm{~min}$, and the instantaneous moisture content was calculated using Equation 1:

$$
M=\left(\frac{W_{0}\left(M_{0}-1\right)+W}{W}\right)
$$

where $M$ and $M_{0}$ are the moisture content at any given time $\left(\mathrm{g}_{\text {water }} / \mathrm{g}_{\text {wet matter }}\right)$ and the initial moisture content $\left(\mathrm{g}_{\text {water }} / \mathrm{g}_{\text {wet matter }}\right)$, respectively and $W$ and $W_{0}$ are the mass of samples at any given time $(\mathrm{g})$ and the initial mass of fresh samples $(\mathrm{g})$, respectively.

\subsection{Determination of effective diffusivity $\left(D_{\text {eff }}\right)$ and activation energy $\left(E_{a}\right)$}

One dimensional diffusion is considered and Fick's diffusion equation is used for the simple analysis of the only diffusion-based thin layer drying equation (Demiray \& Tulek, 2012). Taking the isotropic behaviour of the samples into account with regard to the water diffusivity, to define the mass transfer process, Fick's second law of unsteady state diffusion can be used as Equation 2:

$\frac{\partial M}{\partial t}=\operatorname{Div}\left(D_{e f f}(\operatorname{grad} M)\right)$

By assuming uniform moisture distribution, negligible external resistance, constant diffusivity and negligible shrinkage through drying process, the Equation 2 can be solved by using the separation of variables. For different solid geometries an analytically solution has given for Equation 2. For an infinite slab, it is written as Equation 3 (Alibas, 2014):

$$
M R=\frac{8}{\pi^{2}} \sum_{n=0}^{\infty} \frac{1}{(2 n+1)^{2}} \exp \left(-\frac{(2 n+1)^{2} \pi^{2} D_{e f f} t}{4 L^{2}}\right)
$$

where $D_{e f p} L$, and $t$ are the effective diffusivity $\left(\mathrm{m}^{2} \mathrm{~s}^{-1}\right)$, half thickness of the slab (m), and the drying time (s), respectively. In addition, $M R$ is moisture ratio defined as Equation 4:

$$
M R=\frac{M-M_{e}}{M_{0}-M_{e}}
$$

In Equation $4, M_{e}$ is equilibrium moisture content of drying samples $\left(\mathrm{g}_{\text {water }} / \mathrm{g}_{\text {wet matter }}\right)$.

For long drying periods, Equation 3 can be simplified to only the first term of the series and it is written in logarithmic form as Equation 5 (Alibas, 2014):

$$
\ln M R=\ln \frac{8}{\pi^{2}}-\left(\frac{\pi^{2} D_{e f f} t}{4 L^{2}}\right)
$$

By plotting experimental data in term of $\ln (M R)$ against drying time, a straight line was obtained and the effective moisture diffusivity was calculated using Equation 6:

$$
D_{\text {eff }}=-\left(\frac{4 L^{2}}{\pi^{2}}\right) \times(\text { slope of line })
$$

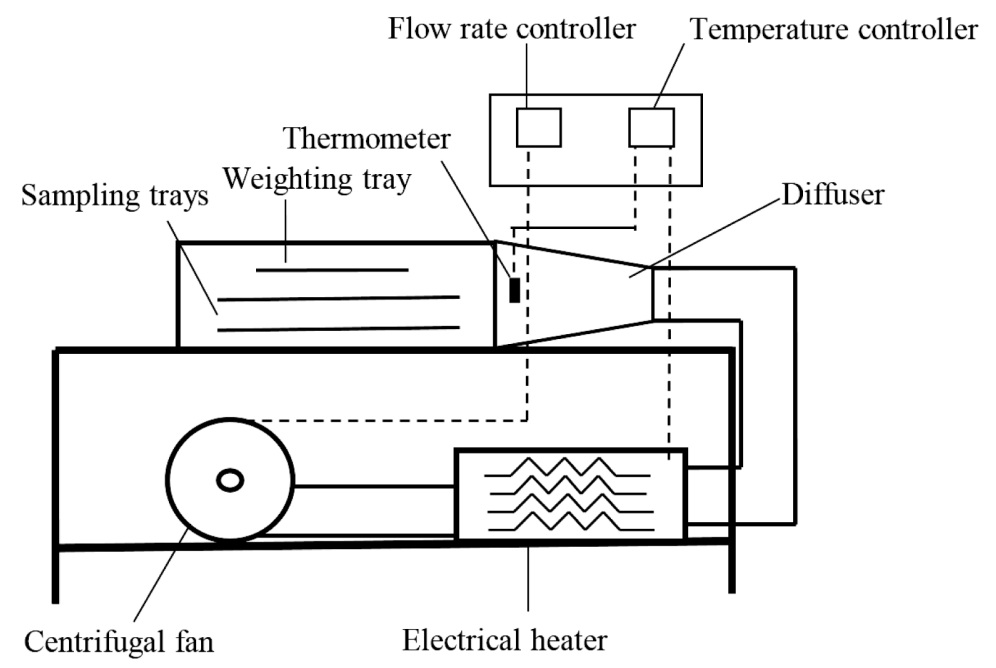

Figure 1. A schematic view of the dryer set up. 
To determine the activation energy, the effective moisture diffusivity was related with drying temperature as Equation 7:

$$
D_{e f f}=D_{0} \exp \left(-\frac{E_{a}}{R T_{a b s}}\right)
$$

where $D_{0}$ is Arrhenius constant or the constant equivalent to the diffusivity at infinitely high temperature $\left(\mathrm{m}^{2} \mathrm{~s}^{-1}\right), R$ is the universal gas constant $\left(8.314 \times 10^{-3} \mathrm{~kJ} \mathrm{~mol}^{-1} \mathrm{k}^{-1}\right), T_{a b s}$ is the absolute temperature $\left({ }^{\circ} \mathrm{k}\right)$, and $E_{a}$ is the activation energy $\left(\mathrm{kJ} \mathrm{mol}^{-1}\right)$.

The graph of $\ln \left(D_{\text {eff }}\right)$ against $1 / T_{a b s}$ was plotted, and its slope was used to determine the activation energy as Equation 8 (Beigi, 2015):

$-($ slope of line $) \times R=E_{a}$

\subsection{Energy consumption}

In a hot air dryer, energy consumption is estimated from the sum of thermal energy $\left(E_{t h}\right)$ and mechanical energy $\left(E_{\text {mec }}\right)$. Equation 9 was used to calculated thermal energy (Motevali et al., 2014):

$$
E_{t h}=\left(A \cdot v \cdot \rho_{a} \cdot C_{a} \cdot \Delta T\right) \cdot t
$$

where $A, v, \Delta \mathrm{T}$ are tray area $\left(\mathrm{m}^{2}\right)$, air flow rate $\left(\mathrm{m} \mathrm{s}^{-1}\right)$ and temperature difference $(\mathrm{K})$, respectively. Also, $\rho_{a}$ and $C_{a}$ are density $\left(\mathrm{kg} \mathrm{m}^{-3}\right)$ and specific heat capacity $\left(\mathrm{kJ} \mathrm{kg}^{-1} \mathrm{~K}^{-1}\right)$ of inlet air, respectively, and are calculated using Equation 10 (Naghavi et al., 2010) and Equation 11 (Aghbashlo et al., 2012), respectively:

$\rho_{a}=\frac{101.325}{0.287 T_{a b s}}$

$C_{a}=1.04841-\frac{3.83719 T_{a b s}}{10^{4}}+\frac{9.45378 T_{a b s}^{2}}{10^{7}}-\frac{5.49031 T_{a b s}^{3}}{10^{10}}+\frac{7.92981 T_{a b s}^{4}}{10^{14}}$

The mechanical energy consumed by blower was determined as Equation 12 (Vieira et al., 2007):

$E_{\text {mec }}=\Delta P \cdot m_{\text {air }} \cdot t$

where $\Delta P$ and $m_{\text {air }}$ are pressure difference (mbar) and inlet air mass $(\mathrm{kg})$, respectively.

\subsection{Thermal efficiency}

The thermal efficiency indicates how well an energy conversion or transfer process is accomplished in a device that uses thermal energy. In drying term, thermal efficiency is defined as the ratio of latent moisture evaporation heat of the sample to the amount of required energy to evaporate moisture from free water. Thermal efficiency was calculated using Equation 13 (Hebbar et al., 2004):

$\eta_{t h}=\frac{P \cdot A \cdot h_{f g} \cdot m_{w}}{F \cdot t}$

where $P, h_{f g}$ and $F$ are sample loading density $\left(\mathrm{kg} \mathrm{m}^{-2}\right)$, latent heat of vaporisation $\left(\mathrm{kJ} \mathrm{kg}^{-1}\right)$ and utilized capacity of heating source $(\mathrm{kW})$, respectively. Additionally, $m_{w}$ is the mass of removed water $(\mathrm{kg})$, and was calculated using Equation 14:
$m_{w}=\frac{W_{0}\left(M_{0}-M_{f}\right)}{100-M_{f}}$

$M_{f}$ is the final moisture content of drying samples ( $\left.g_{\text {water }} / \mathrm{g}_{\text {wet matter }}\right)$.

Equation 15 was used to calculate the latent heat of vaporisation (Aghbashlo et al., 2012):

$\begin{cases}h_{f g}=2.503 \times 10^{6}-2.386 \times 10^{3}\left(T_{a b s}-273.16\right) & 273.16 \leq T_{a b s}\left({ }^{\circ} \mathrm{K}\right) \leq 338.72 \\ h_{f g}=\left(7.33 \times 10^{12}-1.60 \times 10^{7} T_{a b s}\right)^{0.5} & 338.72 \leq T_{a b s}\left({ }^{\circ} \mathrm{K}\right) \leq 533.16\end{cases}$

where $T_{a b s}$ is the absolute temperature of drying air.

\subsection{Energy efficiency}

Energy efficiency is defined as the ratio of the energy used for evaporation of moisture from the sample to the total consumed energy, and can be derived by using energy balance equation based on the first law of thermodynamics. Energy efficiency was determined using Equation 16 (Vieira et al., 2007):

$\eta_{e}=\frac{Q_{w}}{E_{t h}+E_{\text {mec }}}$

where $Q_{w}$ is consumed energy for the moisture evaporation $(\mathrm{kJ})$, and was calculated using Equation 17 (Motevali et al., 2014):

$Q_{w}=h_{f g} \cdot m_{w}$

\subsection{Drying efficiency}

Drying efficiency is defined as the ratio of the energy utilized for heating the sample for moisture evaporation, to the total consumed energy and was determined using Equation 18 (Vieira et al., 2007):

Drying efficiency $=\frac{Q_{w}+Q_{m}}{E_{t h}+E_{m e c}}$

In Equation $18, Q_{m}$ is the energy utilized for sample heating $(\mathrm{kJ})$ and was calculated using Equation 19:

$Q_{m}=W_{d m} C_{m}\left(T_{m, o}-T_{m, i}\right)$

In Equation 19, $W_{d m}$ is the weight of the dry material $(\mathrm{kg})$, and $T_{m, i}$ and $T_{m, o}$ are the inlet and outlet material temperature $(\mathrm{K})$, respectively. Also, $C_{m}$ is the moist material specific heat, and for apple, defined as Equation 20 (Mykhailyk \& Lebovka, 2014):

$C_{m}=C_{w}+\left(C_{w}-C_{d}\right)(M-1)$

where $C_{w}$ and $C_{d}$ are specific heats of water (approximately $4186 \mathrm{~J} / \mathrm{kg}$ $\mathrm{K}$ for the $0-80{ }^{\circ} \mathrm{C}$ temperature) and dry matter, respectively.

\section{Results and discussion}

\subsection{Dehydration characteristics}

For each drying condition, the experiments were replicated three times and the average values were used. In each experiment, the sample lot was dried to the final moisture content of about 
$0.10 \mathrm{~g}_{\text {water }} / \mathrm{g}_{\text {wet matter }}$ (Sacilik \& Elicin, 2006). Table 1 shows the drying duration, average dehydration rate and effective moisture diffusivity values at different drying conditions. From the table, it is noticed that drying time decreased as the air temperature and flow rate increased from 50 to $70{ }^{\circ} \mathrm{C}$ and 1 to $2 \mathrm{~m} \mathrm{~s}^{-1}$, respectively. Similar results have been reported in the literature for air temperature and flow rate influences on dehydration rate for chamomile (Motevali et al., 2014), native cassava starch (Aviara et al., 2014), and potato pulp waste (Carvalho et al., 2014). Drying duration of agricultural materials can be affected by some factors such as indigenous properties, initial and final moisture contents of the product, drying method and drying conditions. Higher temperatures and flow rates of drying air facilitate the heat transfer rate between thermal source and the material leading to faster moisture evaporation and lower drying time.

The moisture diffusivity for each drying condition was calculated using Equation 7, and the results are listed in Table 1. The results show that the moisture diffusivity values were in the range of $6.75 \times 10^{-10}-1.28 \times 10^{-9} \mathrm{~m}^{2} \mathrm{~s}^{-1}$, which are generally within the range given for food materials moisture diffusion $\left(10^{-11}\right.$ to $\left.10^{-6} \mathrm{~m}^{2} \mathrm{~s}^{-1}\right)$ (Olanipekun et al., 2014). The obtained moisture diffusivity values for the apple slices agree well with the values reported for different vegetables and fruits in the literature. Doymaz (2011) reported the diffusivity values to be in the range of $9.32 \times 10^{-11}-1.76 \times 10^{-10} \mathrm{~m}^{2} \mathrm{~s}^{-1}$ for sweet potato dried at temperatures of 50,60 and $70^{\circ} \mathrm{C}$; and constant air velocity of $2 \mathrm{~m} \mathrm{~s}^{-1}$. Minaei et al. (2012) reported effective moisture diffusion coefficient of pomegranate arils in the ranges of $0.74 \times 10^{-10} 52.5 \times 10^{-10} \mathrm{~m}^{2} \mathrm{~s}^{-1}$ and $3.43 \times 10^{-10}$ to $32.05 \times 10^{-10} \mathrm{~m}^{2} \mathrm{~s}^{-1}$ for vacuum and microwave drying, respectively. Tulek (2011) dried mushroom slice at temperatures of 50,60 and $70{ }^{\circ} \mathrm{C}$ and air velocity of $0.2 \mathrm{~m} \mathrm{~s}^{-1}$ and reported the effective moisture diffusivity to be in the range of $9.619 \times 10^{-10}$ to $1.556 \times 10^{-9} \mathrm{~m}^{2} \mathrm{~s}^{-1}$.

From Table 1, it can be seen that any increase in air temperature increased the effective diffusivity value. This observation is in agreement with the results reported for agricultural products e.g., kale (Mwithiga \& Olwal, 2005) and red chillies (Kaleemullah \& Kailappan, 2006). In fact, an increase in temperature causes a decrease in water viscosity and increases the activity of water molecules. These phenomena facilitate diffusion of water molecules in object capillaries, consequently increasing the moisture diffusivity. In addition, the effect of drying air flow rate on moisture diffusivity can be seen where any increment in air flow rate increased the moisture diffusivity of the samples. Similar results have been reported in the literature for fruits and vegetables e.g., sweet potato (Singh \& Pandey, 2012) and mushroom (Ghanbarian et al., 2015).

The activation energy $\left(E_{a}\right)$ was calculated by plotting the graph of $\ln \left(D_{e f f}\right)$ against $1 / T_{a b s}$ (Figure 2$)$ and using Equation 7. The $E_{a}$ values were $17.77,19.75$ and $25.41 \mathrm{~kJ} \mathrm{~mol}^{-1}$, respectively. The obtained activation energy is within the general range reported for food materials (1.27-110 kJ mol-1) (Aghbashlo et al., 2008).

\subsection{Total energy consumption and energy efficiency}

The total energy consumed in drying apple slices at different air temperatures and flow rates is presented in Figure 3. From this figure, it can be seen that at each air temperature, total energy utilization increases with an increment in air velocity. In addition, at each air flow rate, energy consumption of drying process decreases with increasing air temperature. These observations are in agreement with the results reported for thin layer drying of pomegranate arils (Motevali et al., 2011) Russian olive (Abbaszadeh et al., 2012) and chamomile (Motevali et al., 2014).

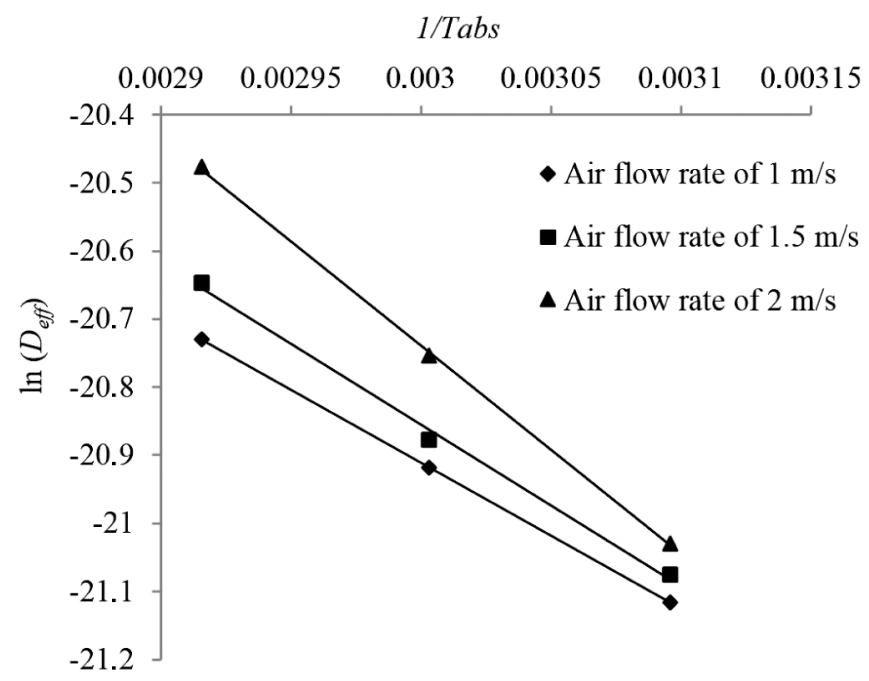

Figure 2. Arrhenius-type relationship between effective diffusivity and reciprocal absolute temperature.

Table 1. Values of drying time and average drying rate of apple slices.

\begin{tabular}{|c|c|c|c|c|}
\hline $\begin{array}{c}\text { Air temperature } \\
\left({ }^{\circ} \mathrm{C}\right)\end{array}$ & $\begin{array}{l}\text { Air flow rate } \\
\quad\left(\mathrm{m} \mathrm{s}^{-1}\right)\end{array}$ & $\begin{array}{l}\text { Drying time } \\
\quad(\mathrm{min})\end{array}$ & $\begin{array}{l}\text { Average drying rate } \\
\quad\left(\mathrm{g}_{\text {water }} \min ^{-1}\right)\end{array}$ & $\begin{array}{l}\text { Effective moisture } \\
\text { diffusivity }\left(\mathrm{m}^{2} \mathrm{~s}^{-1}\right)\end{array}$ \\
\hline \multirow{3}{*}{50} & 1 & 225 & 1.78 & $6.75 \times 10^{-10}$ \\
\hline & 1.5 & 180 & 2.22 & $7.03 \times 10^{-10}$ \\
\hline & 2 & 160 & 2.49 & $7.37 \times 10^{-10}$ \\
\hline \multirow{3}{*}{60} & 1 & 155 & 2.58 & $8.24 \times 10^{-10}$ \\
\hline & 1.5 & 125 & 3.19 & $8.58 \times 10^{-10}$ \\
\hline & 2 & 110 & 3.64 & $9.69 \times 10^{-10}$ \\
\hline \multirow{3}{*}{70} & 1 & 135 & 2.96 & $9.93 \times 10^{-10}$ \\
\hline & 1.5 & 105 & 3.81 & $1.08 \times 10^{-9}$ \\
\hline & 2 & 95 & 4.21 & $1.28 \times 10^{-9}$ \\
\hline
\end{tabular}


Figure 4 shows values of energy efficiency for the apple slices drying. Energy efficiency values were in the range of $2.87-9.11 \%$. These values agree well with those reported in the literature. Motevali et al. (2014) dried chamomile flowers in a convective dryer at air temperatures of $45-70{ }^{\circ} \mathrm{C}$ and velocities of $0.5-1.5 \mathrm{~m} \mathrm{~s}^{-1}$, and determined the energy efficiency to be in the range of 1.91-6.76\%. Aghbashlo et al. (2012) reported energy efficiency values for spray drying of fish oil microencapsulation

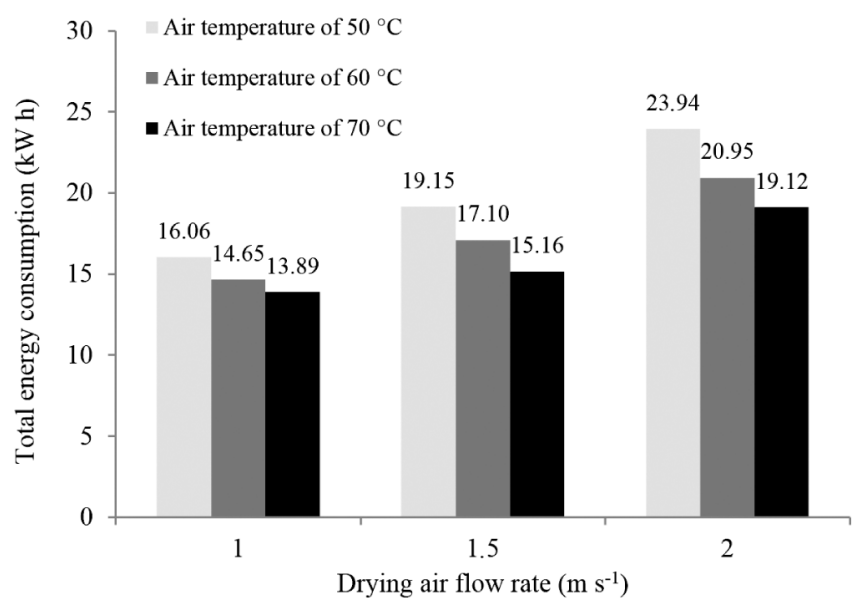

Figure 3. Energy consumption (kWh) for drying of apple slices at different air temperatures and flow rates.

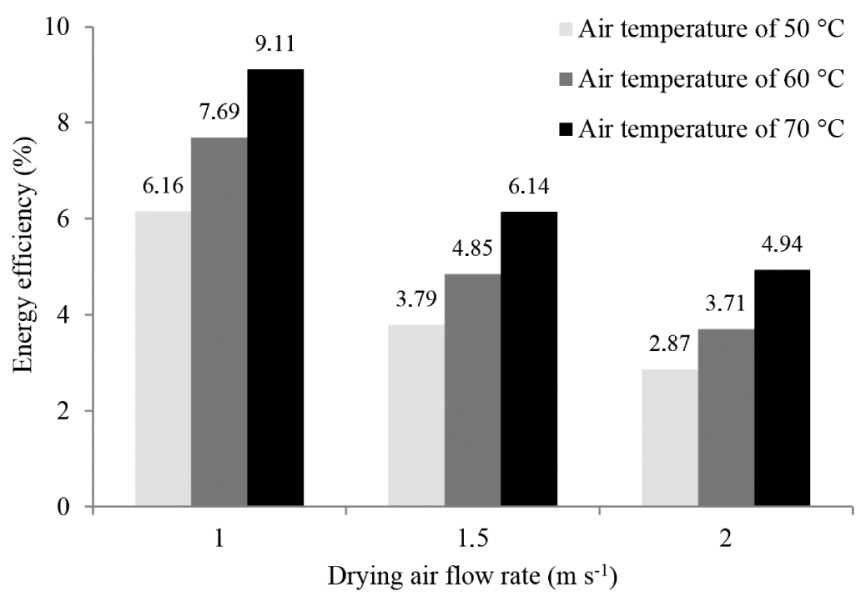

Figure 4. Energy efficiency for drying of apple slices at different air temperatures and flow rates.

Table 2. Values of the thermodynamic parameters for drying apple slices.

\begin{tabular}{cccc}
\hline $\begin{array}{c}\text { Air temperature } \\
\left({ }^{\circ} \mathrm{C}\right)\end{array}$ & $\begin{array}{c}\text { Air flow rate } \\
\left(\mathrm{m} \mathrm{s}^{-1}\right)\end{array}$ & $\begin{array}{c}\text { Thermal } \\
\text { efficiency }(\%)\end{array}$ & $\begin{array}{c}\text { Drying } \\
\text { efficiency }(\%)\end{array}$ \\
\hline \multirow{3}{*}{50} & 1 & 6.57 & 7.33 \\
& 1.5 & 4.40 & 4.52 \\
& 2 & 3.70 & 3.42 \\
\hline \multirow{3}{*}{60} & 1 & 8.06 & 9.77 \\
& 1.5 & 5.40 & 6.16 \\
& 2 & 4.47 & 4.71 \\
\hline \multirow{3}{*}{70} & 1 & 9.44 & 12.29 \\
& 1.5 & 6.68 & 8.30 \\
& 2 & 5.72 & 6.68 \\
\hline
\end{tabular}

at temperatures between 140 and $180{ }^{\circ} \mathrm{C}$ to be in the range of 7.48-8.54\%. According to Figure 4 , the minimum and maximum energy efficiency values were achieved at $50{ }^{\circ} \mathrm{C}$ and $2 \mathrm{~m} \mathrm{~s}^{-1}$, and at $70^{\circ} \mathrm{C}$ and $1 \mathrm{~m} \mathrm{~s}^{-1}$, respectively. Moreover, the obtained results indicate that increasing temperature increases the energy efficiency, while increasing the air flow rate decreases the energy efficiency.

\subsection{Thermodynamic parameters}

Thermal efficiency and drying efficiency were calculated using Equation 5 and Equation 10, respectively, and the results are shown in Table 2. From this table, it is can be seen that any increment in the air temperature increases thermal and drying efficiencies while any increment in the air flow rate decreases both of them. The minimum drying and thermal efficiencies with 3.42 and $3.70 \%$ values, respectively, were obtained for drying treatment of $50{ }^{\circ} \mathrm{C}$ and $2 \mathrm{~m} \mathrm{~s}^{-1}$ treatment, while the maximum values with 12.29 and $9.44 \%$, respectively, were achieved at $70^{\circ} \mathrm{C}$ and $1 \mathrm{~m} \mathrm{~s}^{-1}$ treatment. From Table 2 and Figure 4, it is revealed that thermal efficiency and energy efficiency values are very close. In fact, in convective hot air dryers, the main portion of energy consumption is allocated to heating up the air (thermal energy) and mechanical energy consumption is significantly lower than that of thermal energy. In the present study, average shares of thermal and mechanical energy were estimated to be approximately 98 and 2\%, respectively. Additionally, it can be seen that drying efficiency is higher than thermal and energy efficiencies since part of the consumed energy is spent to increase temperature of the drying product $\left(Q_{m}\right)$. These results agree well with those reported in the literature (Vieira et al., 2007; Jindarat et al., 2011; Motevali et al., 2014).

\section{Conclusions}

In this study, apple slices were dried in a hot air dryer and influences of air properties on energy parameters and drying behaviour of the samples were investigated. According to the obtained results, it was seen that dehydration time decreased as the air temperature and flow rate increased. The effective moisture diffusivity values were in the range of $6.75 \times 10^{-10}-1.28 \times 10^{-9} \mathrm{~m}^{2} \mathrm{~s}^{-1}$, and increased with both increasing air temperature and air flow rate. At each air temperature, total energy consumption increased with increasing air velocity and at each air flow rate, decreased with increasing air temperature. Energy efficiency values were in the range of 2.87-9.11\%. Any increment in the air temperature increased thermal and drying efficiencies while any increment in the air flow rate decreased both of them. Finally, it is concluded that higher temperatures and lower flow rates for drying air cause better energy efficiencies during drying process.

\section{References}

Abbaszadeh, A., Motevali, A., Ghobadian, B., Khoshtaghaza, M. H., \& Minaei, S. (2012). Effect of air velocity and temperataure on energy and effective moisture diffusivity for Russian olive (Elaeagnusan gastifolial L.) in thin-layer drying. Iranian Journal of Chemistry and Chemical Engineering, 31(1), 75-79.

Aghbashlo, M., Kianmehr, M. H., \& Samimi-Akhijahani, H. (2008). Influence of drying conditions on the effective moisture diffusivity, energy of activation and energy consumption during the thin- 
layer drying of berberis fruit (Berberidaceae). Energy Conversion and Management, 49(10), 2865-2871. http://dx.doi.org/10.1016/j. enconman.2008.03.009.

Aghbashlo, M., Mobli, H., Rafiee, S., \& Madadlou, A. (2012). Energy and exergy analyses of the spray drying process of fish oil microencapsulation. Biosystems Engineering, 111(2), 229-241. http:// dx.doi.org/10.1016/j.biosystemseng.2011.12.001.

Aghbashlo, M., Mobli, H., Rafiee, S., \& Madadlou, A. (2013). A review on exergy analysis of drying processes and systems. Renewable \& Sustainable Energy Reviews, 22, 1-22. http://dx.doi.org/10.1016/j. rser.2013.01.015.

Alibas, I. (2014). Mathematical modeling of microwave dried celery leaves and determination of the effective moisture diffusivities and activation energy. Food Science and Technology, 34(2), 394-401. http://dx.doi.org/10.1590/S0101-20612014005000030.

Aviara, N. A., Onuoha, L. N., Falola, O. E., \& Igbeka, J. C. (2014). Energy and exergy analyses of native cassava starch drying in a tray dryer. Energy, 73, 809-817. http://dx.doi.org/10.1016/j.energy.2014.06.087.

Beigi, M. (2015). Hot air drying of apple slices: dehydration characteristics and quality assessment. Heat and Mass Transfer. In press. http:// dx.doi.org/10.1007/s00231-015-1646-8.

Carvalho, W. T., Oliveira, T. F., Silva, F. A., Caliari, M., \& Soares Júnior, M. (2014). Drying kinetics of potato pulp waste. Food Science and Technology, 34(1), 116-122. http://dx.doi.org/10.1590/S010120612014000100017.

Demiray, E., \& Tulek, Y. (2012). Thin-layer drying of tomato (Lycopersicum esculentum Mill. cv. Rio Grande) slices in a convective hot air dryer. Heat and Mass Transfer, 48(5), 841-847. http://dx.doi.org/10.1007/ s00231-011-0942-1.

Doymaz, I. (2011). Thin-layer drying characteristics of sweet potato slices and mathematical modelling. Heat and Mass Transfer, 47(3), 277-285. http://dx.doi.org/10.1007/s00231-010-0722-3.

Ghanbarian, D., Baraani Dastjerdi, M., \& Torki-Harchegani, M. (2015). Mass transfer characteristics of bisporus mushroom (Agaricus bisporus) slices during convective hot air drying. Heat and Mass Transfer. http://dx.doi.org/10.1007/s00231-015-1629-9.

Hebbar, H. U., Vishwanathan, K. H., \& Ramesh, M. N. (2004). Development of combined infrared and hot air dryer for vegetables. Journal of Food Engineering, 65(4), 557-563. http://dx.doi.org/10.1016/j. jfoodeng.2004.02.020.

Jindarat, W., Rattanadecho, P., Vongpradubchai, S., \& Pianroj, Y. (2011). Analysis of energy consumption in drying process of non-hygroscopic porous packed bed using a combined multi-feed microwave-convective air and continuous belt system (CMCB). Drying Technology, 29(8), 926-938. http://dx.doi.org/10.1080/073 73937.2011.560318.

Kaleemullah, S., \& Kailappan, R. (2006). Modelling of thin-layer drying kinetics of red chillies. Journal of Food Engineering, 76(4), 531-537. http://dx.doi.org/10.1016/j.jfoodeng.2005.05.049.
Minaei, S., Motevali, A., Ahmadi, E., \& Azizi, M. H. (2012). Mathematical models of drying pomegranate arils in vacuum and microwave dryers. Journal of agricultural Science and Technology, 14, 311-325.

Motevali, A., Minaei, S., \& Khoshtagaza, M. H. (2011). Evaluation of energy consumption in different drying methods. Energy Conversion and Management, 52(2), 1192-1199. http://dx.doi.org/10.1016/j. enconman.2010.09.014.

Motevali, A., Minaei, S., Banakar, A., Ghobadian, B., \& Khoshtaghaza, M. H. (2014). Comparison of energy parameters in various dryers. Energy Conversion and Management, 87, 711-725. http://dx.doi. org/10.1016/j.enconman.2014.07.012.

Mwithiga, G., \& Olwal, J. O. (2005). The drying kinetics of kale (Brassica oleracea) in a convective hot air dryer. Journal of Food Engineering, 71(4), 373-378. http://dx.doi.org/10.1016/j.jfoodeng.2004.10.041.

Mykhailyk, V., \& Lebovka, N. (2014). Specific heat of apple at different moisture contents and temperatures. Journal of Food Engineering, 123, 32-35. http://dx.doi.org/10.1016/j.jfoodeng.2013.09.015.

Naghavi, Z., Moheb, A., \& Ziaei-Rad, S. (2010). Numerical simulation of rough rice drying in a deep-bed dryer using non-equilibrium model. Energy Conversion and Management, 51(2), 258-264. http:// dx.doi.org/10.1016/j.enconman.2009.09.019.

Olanipekun, B. F., Tunde-Akintunde, T. Y., Oyelade, O. J., Adebisi, M. G., \& Adenaya, T. A. (2014). Mathematical modelling of thin-layer pineapple drying. Journal of Food Processing and Preservation.

Sacilik, K., \& Elicin, A. K. (2006). The thin layer drying characteristics of organic apple slices. Journal of Food Engineering, 73(3), 281-289. http://dx.doi.org/10.1016/j.jfoodeng.2005.03.024.

Schössler, K., Jäger, H., \& Knorr, D. (2012). Effect of continuous and intermittent ultrasound on drying time and effective diffusivity during convective drying of apple and red bell pepper. Journal of Food Engineering, 108(1), 103-110. http://dx.doi.org/10.1016/j. jfoodeng.2011.07.018.

Singh, N. J., \& Pandey, R. K. (2012). Convective air drying characteristics of sweet potato cube (Ipomoea batatas L.). Food and Bioproducts Processing, 90(2), 317-322. http://dx.doi.org/10.1016/j.fbp.2011.06.006.

Soysal, Y. (2004). Microwave drying characteristics of parsley. Biosystems Engineering, 89(2), 167-173. http://dx.doi.org/10.1016/j. biosystemseng.2004.07.008.

Syahrul, S., Hamdullahpur, F., \& Dincer, I. (2002). Exergy analysis of fluidized bed drying of moist particles. Exergy International Journal, 2(2), 87-98. http://dx.doi.org/10.1016/S1164-0235(01)00044-9.

Torki-Harchegani, M., Ghanbarian, D., \& Sadeghi, M. (2015). Estimation of whole lemon mass transfer parameters during hot air drying using different modelling methods. Heat and Mass Transfer, 51(8), 1121-1129. http://dx.doi.org/10.1007/s00231-014-1483-1.

Tulek, Y. (2011). Drying kinetic of oyster mushroom (Pleurotus ostreatus) in a convective hot air dryer. Journal of Agricultural Science and Technology, 13, 655-664.

Vieira, M. G. A., Estrella, L., \& Rocha, S. C. S. (2007). Energy efficiency and drying kinetics of recycled paper pulp. Drying Technology, 25(10), 1639-1648. http://dx.doi.org/10.1080/07373930701590806. 